Ilmenau University of Technology

Institute of Economics

Ilmenau Economics Discussion Papers, Vol. 25, No. 121

\title{
Measuring Competitive Balance in Formula One Racing
}

Oliver Budzinski \& Arne Feddersen

März 2019

Institute of Economics

Ehrenbergstraße 29

Ernst-Abbe-Zentrum

D-98 684 Ilmenau

Phone 03677/69-4030/-4032

Fax 03677/69-4203

http://www.wirtschaft.tu-ilmenau.de

ISSN 0949-3859 


\title{
Measuring Competitive Balance in Formula One Racing
}

\section{Oliver Budzinski* \& Arne Feddersen ${ }^{\#+}$}

\begin{abstract}
The Formula One Championship (F1) is one of the biggest sports businesses in the world. But, however, it seems to astonish that only very few scholarly articles analyze the F1 business. The aim of this study is to contribute to closing two gaps in the existing literature: it contributes (1) to the (sports) economic analysis of the F1 business and (2) to the literature on competitive balance in non-team sports. Like competitive balance in team sport leagues, also for F1 racing three dimensions can be distinguished: (a) race-specific competitive balance, (b) within-season competitive balance, and (c) between-season competitive balance. In addition to classical tools and data, some new and F1 specific indicators, like average lead changes or leading distance, are employed. Also, pitfalls induced especially by the used data source or calculation method are highlighted.
\end{abstract}

Keywords: Formula One Motor Racing, competitive balance, empirical industry study, sports economics

JEL-Codes: Z20, Z21, L83, C01, L13, M21

Professor of Economic Theory, Institute of Economics, Ilmenau University of Technology, Ehrenbergstr. 29, D-98693 Ilmenau, Germany, email: oliver.budzinski@tu-ilmenau.de.

\# Professor MSO, Department of Sociology, Environmental and Business Economics, University of Southern Denmark, Campus Esbjerg, Niels-Bohrs-Vej 9, DK-6700 Esbjerg, Denmark, Phone: 456550-1597, Fax: 45-6550-1091, email: af@sam.sdu.dk.

+ We thank Alina Ahrens, Sarah Kraus and Milena Wehner for helpful assistance. 


\section{Introduction}

The FIA Formula One World Championship (in short: F1) represents in business terms one of the biggest sport events in the world. Its 2017 total revenue is estimated to be approx. 1.8bn US\$ (Sylt, 2018b), making it the economically ninth most important sports industry. At the top of the biggest sporting events is the NFL with approx. 13.68bn US\$ league revenue (statista, 2019) and Major League Baseball with approx. 9.46bn US\$ league revenue (statista, 2018). In terms of revenue generated per event, F1 exceeds its competitors by far with $229 \mathrm{~m}$ US\$ compared to $24 \mathrm{~m}$ US\$ of the NFL (Sylt \& Reid, 2008: 13, 21). F1 achieved an operating profit in 2013 of more than $530 \mathrm{~m}$ US $\$$ against a turnover of about 1.7bn US\$ (Sylt, 2014). Its commercial rights holder is now the Liberty Media Group that acquired F1 for a total enterprise value of 8.0bn US\$ (Nimmervoll, 2016; Liberty Media Group, 2019). In 2015, the annual budgets of the participating teams varied between $83 \mathrm{~m}$ US\$ (Manor) and $467.4 \mathrm{~m}$ US\$ (Mercedes) (Walthert, 2015). Sponsorship of teams amounted to more than 1.5bn US\$ (Reid, 2015). Since 2016, Heineken (races \& trackside advertising; 200m US\$) is one of the biggest single sponsors in motorsport history (Smith, 2018). Teams earned prize money in 2018 in total of $921 \mathrm{~m}$ US\$ (Sy/t, 2018a). With an estimated salary of $42 \mathrm{~m}$ US\$ plus personal sponsorship and endorsements of approx. 9m US\$, that time title defender Lewis Hamilton (Mercedes) was one of the highest paid drivers on the 2018 grid (Badenhausen, 2018).

During the last two decades, an ostensible lack of competitive balance among the participating teams has continuously be one of the biggest issues for the governance of F1. It reached a peak with the domination of Ferrari and Michael Schumacher, winning 6 and 5 consecutive world championships respectively (1999-2004 and 2000-2004 respectively) ${ }^{1}$, and continued afterwards up to the present day with the dominance of Mercedes, winning all constructors' championships between 2014 and 2018, and Lewis Hamilton who lost only one world driver championship during this time period - to his teammate Nico Rosberg (2016). Since March 2013, only three teams ever won a F1 Grand Prix; actually none of the other teams even came close

There are two world champion titles each season - one for the driver who scored the largest amount of points, one for the constructor (team) that scored the largest amount of points. 
to winning a single race during that time. As a consequence of the perceived competitive imbalance, numerous changes of the regulatory framework have been introduced in order to improve competitive balance and even more proposals have been and are controversially discussed. The changes and proposals encompass virtually every dimension of F1 - from the points system to the technical regularities.

Against this background, it seems to astonish that only comparatively few scholarly articles analyze the business and economics of F1. Solitander and Solitander (2010) present a case study on sharing and the thievery of intellectual property in F1, in particular focusing on the 2007 spying scandals involving the leading teams Ferrari, McLaren and Renault. From a technological-managerial perspective, Jenkins and Floyd (2001) trace technological trajectories from 1967 to 1982 in order to identify the evolutionary forces generating dominant designs. Potter (2011) analyzes driver reactions to safety measures, in particular whether more risky driving styles are incentivized. An operations-research paper by Bekker and Lotz (2009) simulates racestrategy choices for three 2005 F1 races. Jenkins (2010) provides a qualitative-historical analysis of the influence of technological discontinuities on competitive performance and advantage. For the time period between 1950 and 2006, he finds that incumbent firms often fail to adapt to the impact of external shocks. The exceptions, firms (teams) whose competitive superiority survived a number of successive discontinuities, are explained with a resource-based management view.

Addressing competition issues in Formula One, Cygan (2007) and Budzinski (2012) discuss the antitrust implications of the so-called FIA case (the European Commission alleged an abuse of dominance by F1s governing body FIA) from the late 1990s. Budzinski and Müller-Kock (2018) analyze antitrust allegations with respect to the financial system and revenue distribution model of F1. They find indication for an abuse of market power by the commercial rights holder as well as for a collusive equilibrium between the governing bodies and the leading teams. On a more general level, Mourao (2017) discusses costs and revenues in F1. He also presents survivor models for the constructors' and drivers' championships and attempts to identify success factors for winning in F1 (Mourao, 2017, 2018). Along similar lines, Stadelmann and Eichenberger (2008), Philipps (2014) as well as Bell, Smith, Sabel, and Jones (2016) try to identify the best driver in F1 history by attempting to isolate 
the impact from the driver on success and separate it from other important influence factors like the competitiveness of the race car, etc. Gutiérrez and Lozano (2014) use the DEA method to discuss the relative efficiencies of F1 team budgets. Depken, Groothuis and Rotthoff(2018) analyze family connections as a success factor in F1. Touching the field of competitive balance in F1 motor racing, Mastromarco and Runkel(2009) as well as Judde, Booth, and Brooks (2013) analyze the impact of rule changes on competitive balance in F1 racing. Kipker (2003) as well as Krauskopf, Langen, and Bünger(2010) explore the effect of competitive balance - among others - on TV ratings. While these papers model competitive balance by means of rather simplistic measures (e.g. standard deviation or Gini coefficient based on championship tables), Schreyer and Torgler (2018) enhance these studies by employing more sophisticated methods and introducing additional control variables, finding a positive effect of competitive balance on viewers' demand.

This scarcity of economic literature on one of the most important sports events in the world stands in line with a more general negligence of competitive balance issues in non-team sports. Another motorsports related competitive balance paper is Berkowitz, Depken, and Wilson (2011) who analyze competitive balance in the NorthAmerican NASCAR touring car series, applying an "adjusted churn" method as well as HHI indices. Outcome uncertainty in cycling is discussed by van Reeth (2013), whereas Du Bois and Heyndels (2007), del Corral (2009), Konjer, Meier, and Wedeking (2017), and Koning (2009) address competitive balance in tennis with the latter additionally discussing speed skating. Eventually, Shmanske(2007) analyses competitive balance in the golf PGA tour.

Since non-teams sports differ from typical team sports, the analysis of competitive balance in non-teams sports requires an adaptation and evolution of competitive balance measuring methods. Furthermore, different non-team sports differ considerably from each other, so that methods often have to be adapted to the unique features of the sports in question. Here, first of all, round-based sports like tennis have to be distinguished from pure head-to-head races like in marathon running, professional cycling or motorsports. This may also explain the comparatively few contributions to this field. 
The aim of this study is to contribute to closing two gaps in the existing literature: It contributes, first, to the (sports) economic analysis of the F1 business and, second, to the literature on competitive balance in non-team sports. Finally, operationalizing measures of competitive balance in motor sport racing could be important for further research in this area. F1 seems to be a particularly well-suited field to analyze the effects of competitive balance on fan demand, ${ }^{2}$ especially with a view to distinguish between the effects of competitive balance and a domestic/local hero preference.

The remainder of this paper is organized as follows. The next section discusses the special characteristics of $\mathrm{F} 1$ and the dimensions of competitive balance in motorsports. Section 3 shows the empirical evidence of these different dimensions of competitive balance in F1, while Section 4 concludes.

\section{Competitive Balance in Non-League Sports}

\subsection{The FIA Formula One World Championship}

The FIA Formula One World Championship comprises a series of single race events ('Grand Prix'; GP) taking place on permanent race circuits and temporary city street circuits all around the world. ${ }^{3}$ In these races, 20 drivers from 10 teams ('constructors $^{4}$ ) fight for points awarded for two different world championships: (i) the world drivers' championship (WDC) and (ii) the world constructors' championship (WCC). In 2019, 25 points are awarded for the winning driver and his team, 18 for the second placed, then $15,12,10,8,6,4,2,1$ for the finishers down to the $10^{\text {th }}$ place. Both drivers of each team can score individually for themselves in the drivers' championship and for their team in the constructors' championship. The title 'world championship' is then awarded at the end of the season to the driver and to the team with the most points. Different from other motor racing series, each team is required

See Berkowitz, Depken, and Wilson (2011) for a comparable analysis for NASCAR racing. For a classification of motor racing circuits see Müller and Budzinski (2014)

3 The 2019 season consists of 21 races in Europe, Asia, South America, North America and Australia and it lasts from March to December. Africa is currently the only continent without a GP, however, there have been GPs in South African and Morocco in former times.

4 In 2019, they consist of car manufacturers (and related companies) like Mercedes, Ferrari, and Renault, specialist race car constructors like for instance McLaren, Williams, Haas as well as the beverages producer Red Bull. 
to build its own monoposto race car (the 'chassis'), whereas engines from (currently 4) different suppliers can be fitted. Technical and sporting regulations have been subject to frequent changes since the inaugural F1 season in 1950 (overview: Mastromarco and Runkel, 2009). This includes several changes of the points system, the race distance, the number of races as well as in the number of participating teams and drivers.

F1's sporting authority is the Fédération Internationale de l'Automobiles (FIA), which is formed by and consists of national motor sports clubs and associations. FIA governs and controls all sporting regulations of F1 through its World Motorsports Council (WMSC), in which stakeholders like the constructors also have a number of seats. Different from the typical teams sports, constructors neither own nor lend/rent the race circuits, whose owners constitute a separate group of stakeholders (and, thus, there are no formal 'home races' in F1). The commercial rights have been transferred on a long-term contract to the Formula One Group (FOG), who takes responsibility for all commercial activities of F1. ${ }^{5}$

\subsection{Dimensions of Competitive Balance in Formula One Motor Racing}

The concept of competitive balance relates to the relative strengths of the teams and individuals competing in a sporting contest. If all the participating teams and drivers (in the case of motor racing) are of equal competitive strength, then competitive balance is maximal. The more few or even one team or driver is superior to its/her competitors, the lower is competitive balance. Sports economic interest in competitive balance traces back to the uncertainty-of-outcome hypothesis (Rottenberg, 1956; Neale, 1964), stating that fans want to see a close fight for the win. An increasing outcome uncertainty is then conjectured to increase demand for watching sports (live or via broadcasts). Outcome uncertainty relates to competitive balance as a high degree of competitive balance should, on average, increase outcome uncertainty, whereas a largely superior competitor will dominate the sport and make con-

5 For more details on the commercial structure of F1 see Budzinski and Müller-Kock (2018) and generally on market-internal financial regulation in sports Budzinski (2018). 
test results ex ante expectable. Thus, a better competitive balance should ceteris paribus increase demand. However, competitive balance is only one of many factors influencing demand and factors like home team or local hero preferences, own-price and cross-price elasticities, media presence, superstar phenomena, etc. may overcompensate the effect of increasing or decreasing competitive balance. As a consequence, the empirical evidence on the influence of competitive balance on demand is mixed (Coates, Humphreys, and Zhou, 2014). Notwithstanding, too much competitive imbalance is likely to hurt the business of any sports. ${ }^{6}$

When comparing F1 to typical team sports, a couple of differences are immediately striking. First, instead of having games of team pairs each matchday, the 20 drivers from 10 teams race head-to-head in each GP. Secondly, points for two different championships (drivers and constructors) are awarded in each single GP. Thirdly, the competitiveness in both championships depends on both the ability of one teams' drivers (drivers' competitiveness) and the technical package (chassis, engines, tyres, etc.; technical competitiveness). The latter implies that competitive imbalance can be due to differences in driving talent but also (and perhaps even more so) to differences in the technical competences of the respective team.

Regarding both championships, three dimensions of competitive balance can be distinguished (Berkowitz, Depken, and Wilson, 2011, p. 255):

(a) within-race competitive balance, i.e. outcome uncertainty regarding a single GP,

(b) within-season competitive balance, i.e. outcome uncertainty regarding the evolution of the points standings, and

(c) inter-season competitive balance, i.e. outcome uncertainty regarding the series of champions in the course of time.

Within-race competitive balance is certainly an important dimension for F1 fans. On the one hand, it can refer to the fight for the victory of the top positions only. For instance, TV broadcasts of F1 races usually focus predominantly on the top contenders. Potential measures for within-race balance include the margin of victory or the

6 For a contemporary overview over concepts, theories and measures of competitive balance see, inter alia, Pawlowski and Nalbantis (2019). 
number of lead changes (Berkowitz, Depken, and Wilson, 2011, pp. 257-258). On the other hand, within-race competitive balance can refer to the overall race, i.e. including what happens further down the grid. The difference between starting and finishing position of a driver can serve as an estimation method here (Berkowitz, Depken, and Wilson, 2011, p. 258).

Regarding within-season competitive balance, i.e. the unfolding of a season, the most obvious measure would probably be a concentration measure like the Herfindahl-Hirschman-Index ( $\mathrm{HHI})$. In order to measure the development of the concentration of performance points over the course of a season, Berkowitz, Depken, and Wilson (2011, p. 259) calculate a points-based HHI before each race.

While both within-race and within-season competitive balance can be viewed to constitute rather similar phenomena for the drivers' and for the constructors' championship, this differs in regard to inter-season competitive balance. The WCC resembles quite closely a league in team sports in that it is predominantly the same teams that compete in different seasons over longer periods. There is some change, in particularly in the very long run, but the same is basically true for teams sports (trade of franchises, enhancement or shrinking of leagues, relegation and promotion in open leagues, etc.). However, looking at inter-season competitive balance of the WDC is connected to the problem of overlapping driver careers. The number of seasons each driver competes in F1 differs and is naturally limited. Moreover, the individual careers overlap. Thus, any defined interval of seasons would comprise some drivers' careers in full and others merely in parts of differing lengths, thereby blurring the explanatory power of the respective measure. This considerably aggravates the measuring of inter-season balance in the drivers' championship.

\section{Competitive Balance in Formula One Motor Racing: Empirical Evidence}

\subsection{Within-race Competitive Balance}

Berkowitz, Depken, and Wilson (2011, p. 257) give some examples on how withinrace competitive balance could be measured. First, the margin of victory could be used. As this measure only gauges the difference between the first and second placed 
driver and does not reveal any information about the competitive balance of the remainder of the drivers, it will be disregarded for this specific analysis.

Second, the number of lead changes can be used as an indicator of competitive balance. Figure 1 displays the development of lead changes in F1 races for all official races since $1950 .{ }^{7}$ Thereby, the left column of the figure plots the number of lead changes for each single race, while the right column shows season averages. The $x-$ axis in the left column figures is displaying the individual F1 GP from the first GP in 1950. However, the label of the axis indicates the first race of each decade instead of the pure race number in order to increase the readability. Additionally, here and in the following, a grey line indicates the measure of competitive balance, while a solid black line depicts a linear trend and a dashed black line a smoothed trend calculated by means of a locally weighted regression (LLR).

Figure 1: Lead changes in F1 races as measure of competitive balance
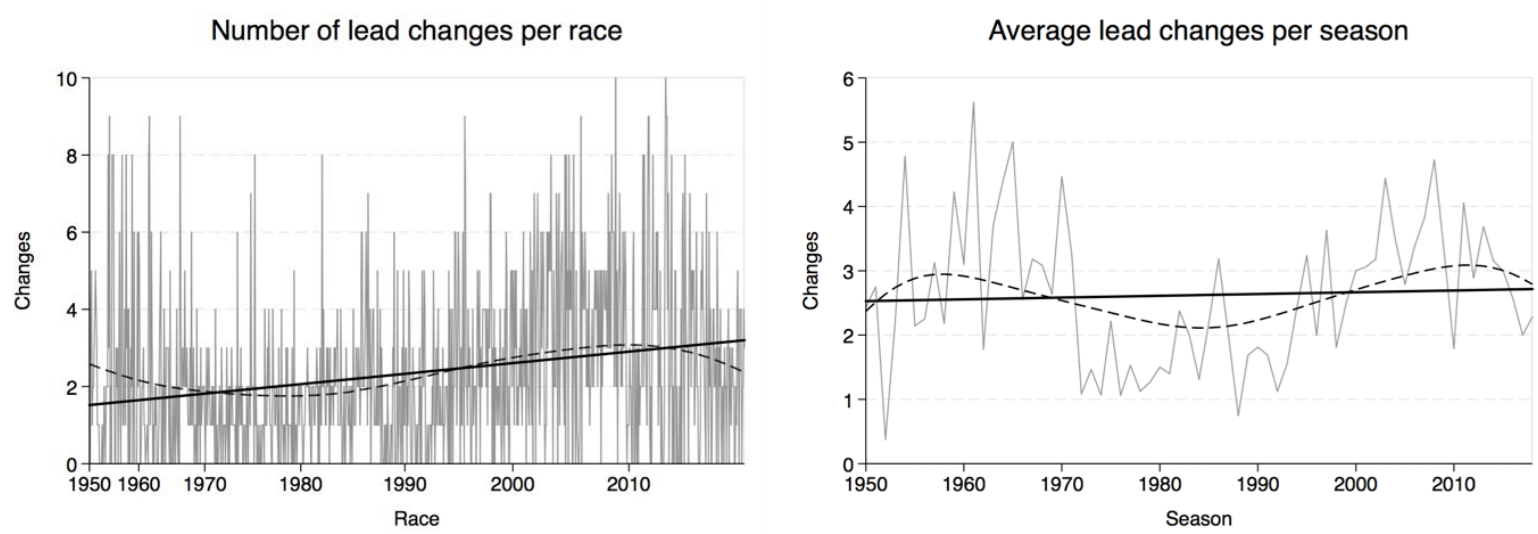

Even if the left column might be a little confusing at first glance, especially the two trend lines are interesting. A clear positive linear trend can be observed. Furthermore, the smoothed LLR trend first declined and reached its minimum around the 1980 season. From this minimum, the smoothed trend indicates an increased number of lead changes during the races with a notable drop after 2010. A quite similar story can be derived from the right column. Here, the smoothed trend follows a comparable pattern and the minimum of the average lead changes can be observed around

\footnotetext{
7 All data for the empirical analysis has been collected from https://www.formula1.com and
} https://www.motorsport-total.com/formel-1/formel-1-datenbank/. 
the mid-1980s. Following this minimum, a strong increase in the smoothed trend can be attested implying also an improvement in competitive balance, while a notable drop can be identified after 2010. It should be noted that the number of lead changes is particularly influenced by certain aspects of the sporting regulations (for instance, introduction versus bans of within-race re-fuelling and mandatory pit-stops for tire changes). Nonetheless, one shortcoming of the number of lead changes as a measure of competitive balance should not be concealed here. As already criticized by Berkowitz, Depken, and Wilson (2011, p. 258), this measure does not reflect how much passing occurred throughout the entire field until the end of the race. Unfortunately, this data is to - our best knowledge - not available for F1.

Calculating the Gini coefficient for the results of the qualifying could be a competitive balance measure which takes the balance throughout the entire field into account. Figure 2 highlights the development of the Gini coefficients based on the distribution of qualifying lap times for each race since 1950, whereas the pole position qualifying lap time is normalized to a value of $100 \%$ and the time gaps of the remaining drivers are specified as three digit percentage value of the qualifying time (e.g. 104.693\%).

Figure 2: Gini coefficient based in qualifying times (in percent)

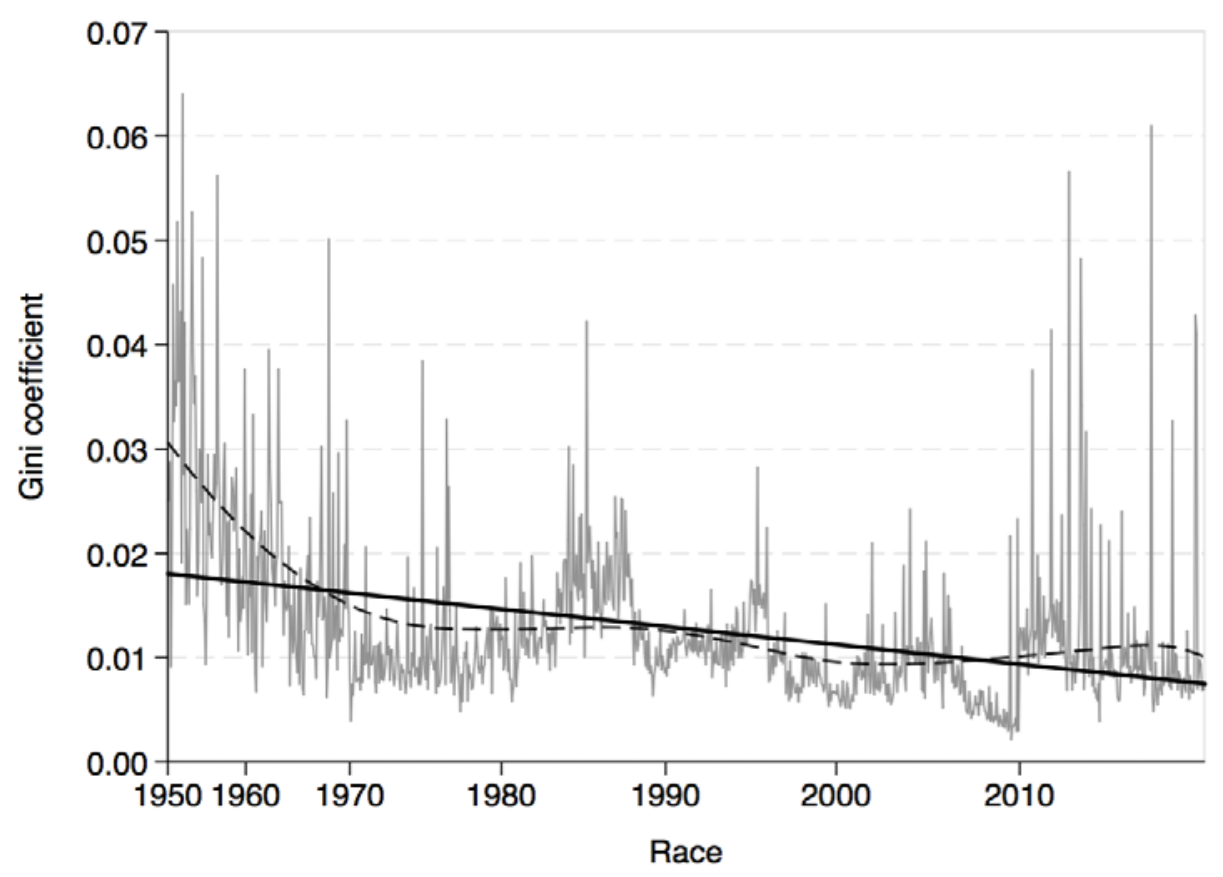


The Gini coefficients reveal some variance between the races, especially during the starting period of the F1 championship. Also a clear negative linear trend can be seen. The smoothed trend confirms the development towards a more balanced competition towards the actual seasons, while there is a slight trend in the opposite direction after 2010.

Finally, Berkowitz, Depken, and Wilson (2011, p. 258) suggest that a measure of competitive balance within a race should reflect the differences between the starting and finishing positions throughout the entire field. They adopted the adjusted churn index developed by Mizak, Neral, and Stair (2007). Instead of this measure, we employ the Spearman rank correlation coefficient to measure the changes between the starting grid and the final result. The ranking of the race results is based on finishing times and laps behind if relevant. For retired drivers the completed race distance is used to rank the drivers. To begin with, a clear positive (long-term) linear trend can be observed, while the smoothed trend decreases at first reaching the minimum around the mid-1980s. Following the minimum, the LLR trend increases. This implies a growing congruence between the grid positions and the final positions and, thus, a decreasing competitive balance.

Figure 3: Spearman's rank correlation coefficient between grid and final race position

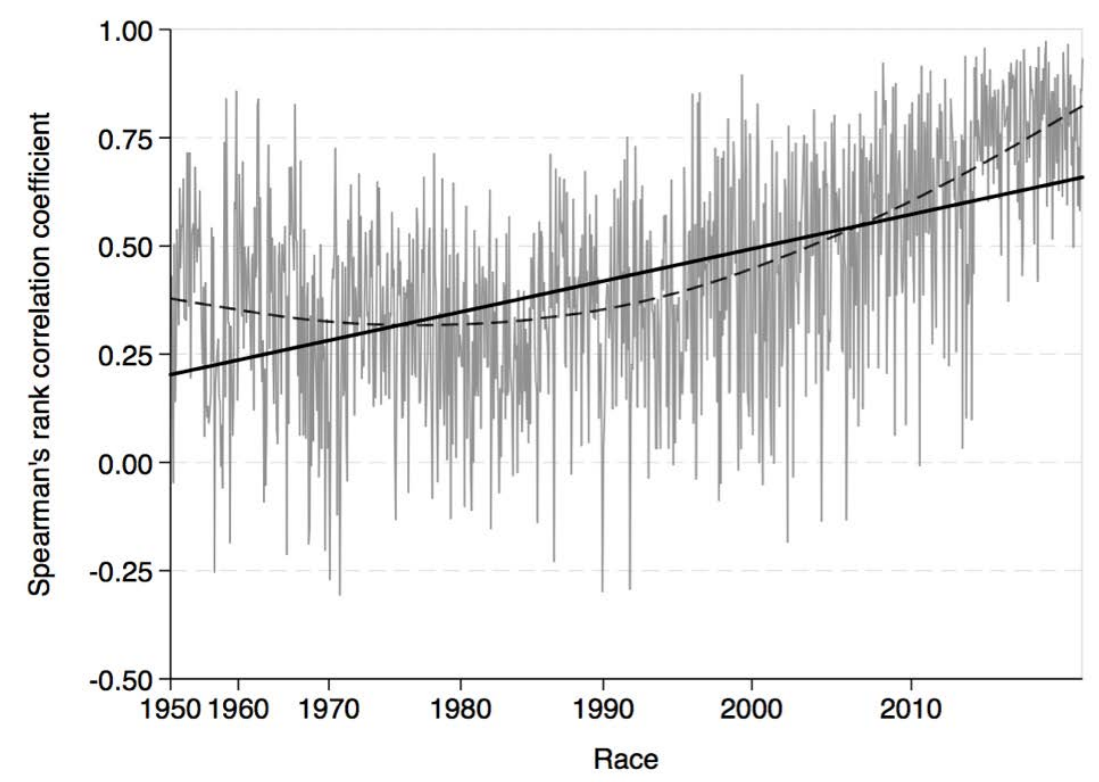




\subsection{Within-season Competitive Balance}

Like in team sport leagues, within-season competitive balance can be measured by means of the final standings of the sporting competition. So far, several measures are employed in the literature. The methods used are, for example, the HHI, the Gini coefficient, standard deviation, coefficient of variation, or the ratio of actual and ideal standard deviation (RSD). It is obvious that the RSD has its legitimacy for team sports leagues considering different schedule length. In this context, however, such a correction mechanism is not necessary. Therefore, we will employ a standard measure of concentration in the following. The Gini coefficient is calculated, analogously to team sport leagues, on the basis of the final standing of each F1 season for both the WDC and the WCC.

When calculating this indicator, some peculiarities have to be taken into consideration. In contrast to team sport leagues, where normally all teams have accumulated at least some points in the final league standing, in F1 only a fraction of the drivers/teams have scored points at the end of the season. This leads to the decision whether the Gini coefficient should be calculated on the basis of the point distribution of the drivers/teams which have accumulated points or on the basis of the point distribution of all enlisted drivers/teams. Obviously, the inclusion of drivers/teams with zero points in the calculation of the index could have a serious impact. 
Figure 4: Competitive balance based on different point distributions
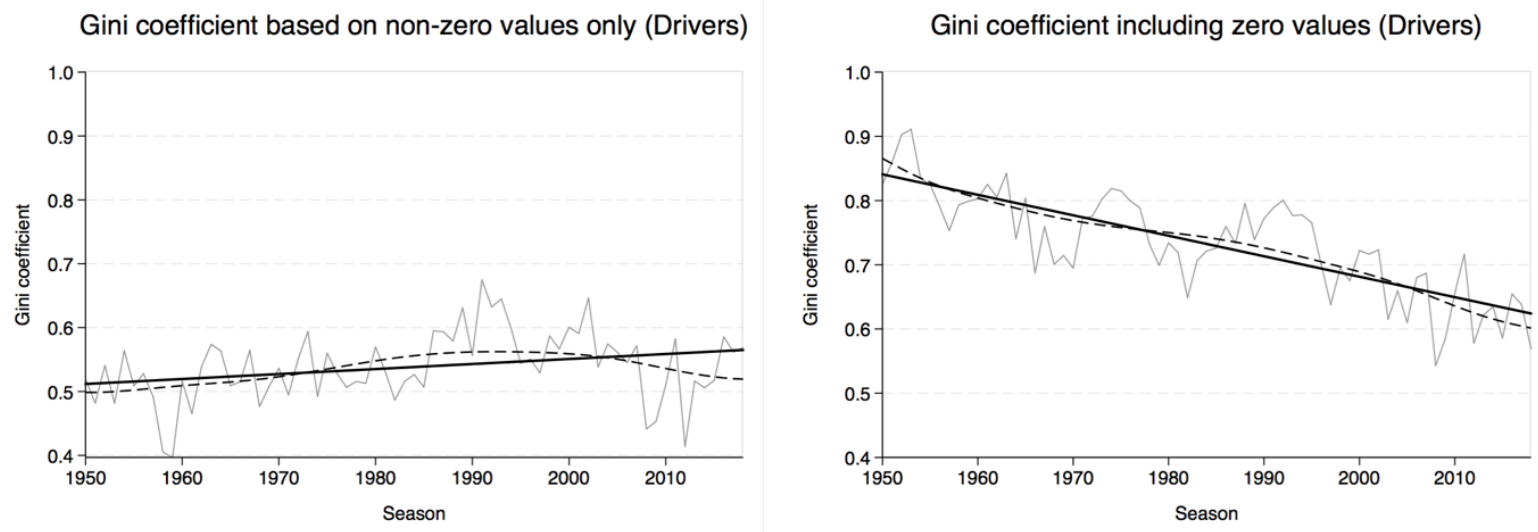

Gini coefficient based on non-zero values only (Teams)
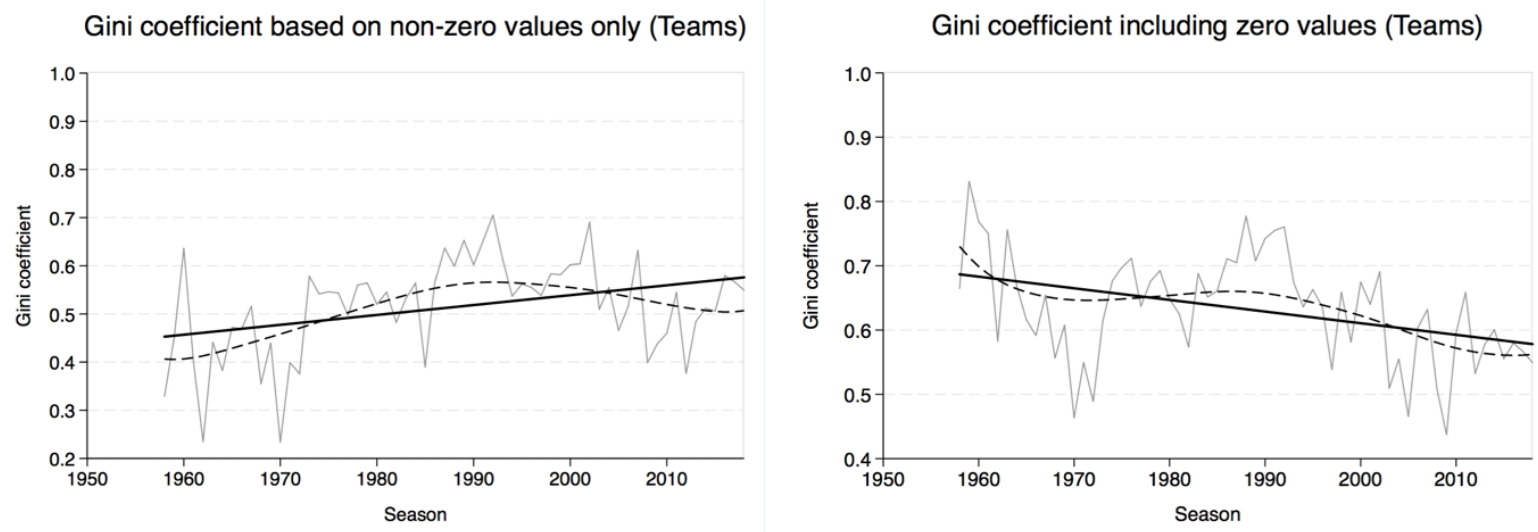

The left column of Figure 4 shows the development of competitive balance according to the Gini coefficients on the basis of the point distribution of all drivers/teams which have been earned at least one point in the final season standing. The grey line indicates the individual values of the Gini coefficients for all 69 seasons since 1950, ${ }^{8}$ while the solid black line is a linear trend and the dashed black line a smoothed trend calculated by means of a locally weighted regression (LLR). For both championships mid-range values of the Gini coefficient can be observed. A clear positive trend is visible indicating a reduction in competitive balance over time. This positive LLR trend can also be confirmed until the early 1990s.

Inspecting the development of competitive balance according to the Gini coefficients on the basis of the point distribution of all drivers/teams including zero values, which is displayed for both championships in the right column, reveal a different picture. First of all, the absolute values of the Gini coefficients are considerably higher than

8 The WCC did not start until 1958. 
in the other case. Second, the overall trend is negative which can be translated into an improvement of competitive balance in both championships over time.

Regarding the fact that the results depend strongly on the decision to include or not include the zero-point participants, one has to be careful when using measures of the competitive balance in motorsports in general or F1 in special. As sport fans might be mindful of more than the top ranked participants, we recommend using the distribution including zero value observations.

When analyzing competitive balance on the basis of the point distribution, it must be considered that FIA changed the points system several time since 1950. For the first ten seasons the drivers finishing first to fifth have been awarded with points (86-4-3-2). From 1960 to 1990 the first six drivers gained championship points (9-6-43-2-1). ${ }^{9}$ Following the 1990 season, the reward for winning was raised to ten points, while the remaining scheme remained unchanged. Starting with the 2003 season, the previous scheme was replaced by a new scheme, now awarding 10-8-6-5-4-3-21 points to the first ten positions. The rule change came at the back of the 2002 season which was dominated by Michael Schumacher who secured the WDC after 11 of 17 races. Since this was viewed negatively from business considerations (especially TV quotas of the final races), a central motivation behind the new points scheme was to delay the WDC win of a dominating driver by awarding him a smaller points advantage from winning (compared to the second placed driver). Thus, in a way, the change of the points system was motivated by competitive balance concerns. Furthermore, the increase of range of awarded positions from top six to top eight was expected to lead to more engaged racing on the respective positions. In an order to increase the incentives for the leading drivers of a GP, the point scheme has been changed to 25-18-15-12-10-8-6-4-2-1 in 2010.

One possible solution regarding the inconsistencies of the point scheme might be the development and implementation of a consistent point scheme according to the final race results. We chose a simple scheme rewarding 10-9-8-7-6-5-4-3-2-1 points to the drivers finishing within the first ten positions. A downside of such an adjust-

9 Only during the 1960 season the winner was awarded eight instead of nine points. 
ment is that the points system in force at a given time represents an important incentive structure for drivers and teams and therefore probably influences the race results. In other words, the results might have been different if they had been run under this consistent point scheme. ${ }^{10}$

Figure 5 displays the development of competitive balance for the two different point schemes respectively, where the calculations include drivers with zero points accumulated at the end of the season. The left column contains the FIA points-based Gini coefficient, while the right column shows the consistent point scheme-based Gini coefficients. At first glance, the index sequences seem to be quite similar. For all four panels of Figure 5, a clear negative trend, implying an increase in competitive balance, can be attested. Moreover, the smoothed trend does not deviate strongly from the linear trend in both cases. At least at the end of the observation period, different pattern of the smoothed trend could be seen. Looking at the figures based on the current FIA scheme, the LLR trend is more or less following the linear trend over the whole observation period more or less closely, while the LLR trend deviates positively from the linear trend at the end of the observation period when using the consistent point scheme.

10 A resulting possible error, while using the consistent point scheme to calculate a measure of competitive balance, cannot be corrected and, thus, has to be considered when interpreting the corresponding figures. 
Figure 5: Competitive balance based on different point schemes
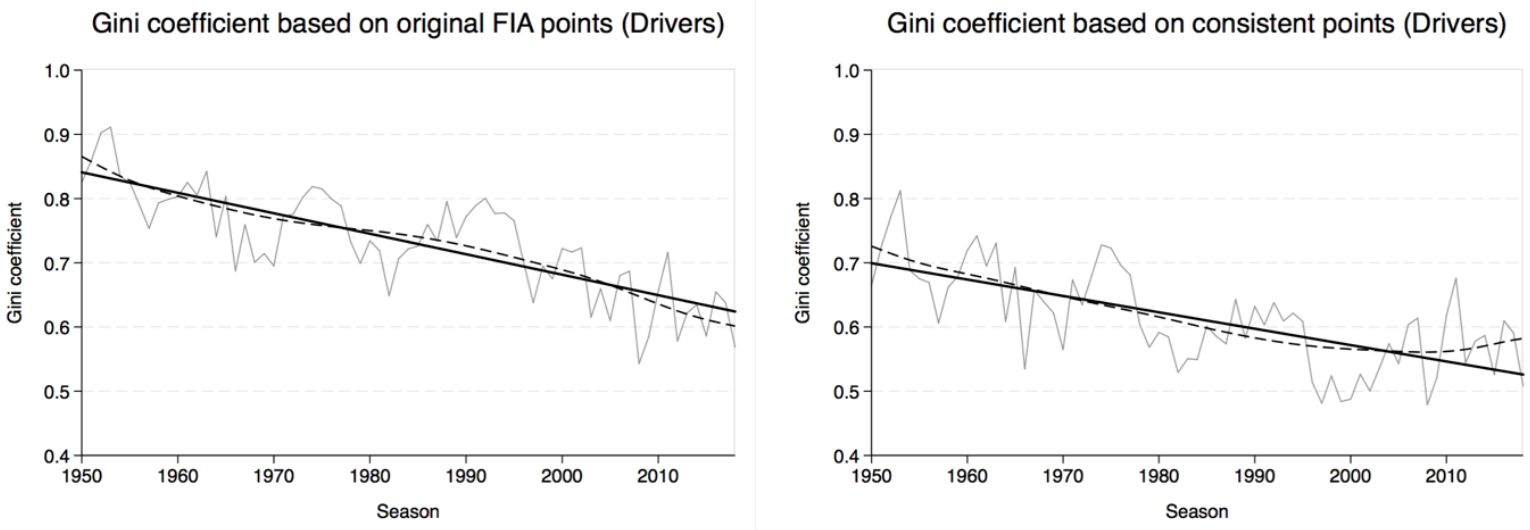

Gini coefficient based on original FIA points (Teams)
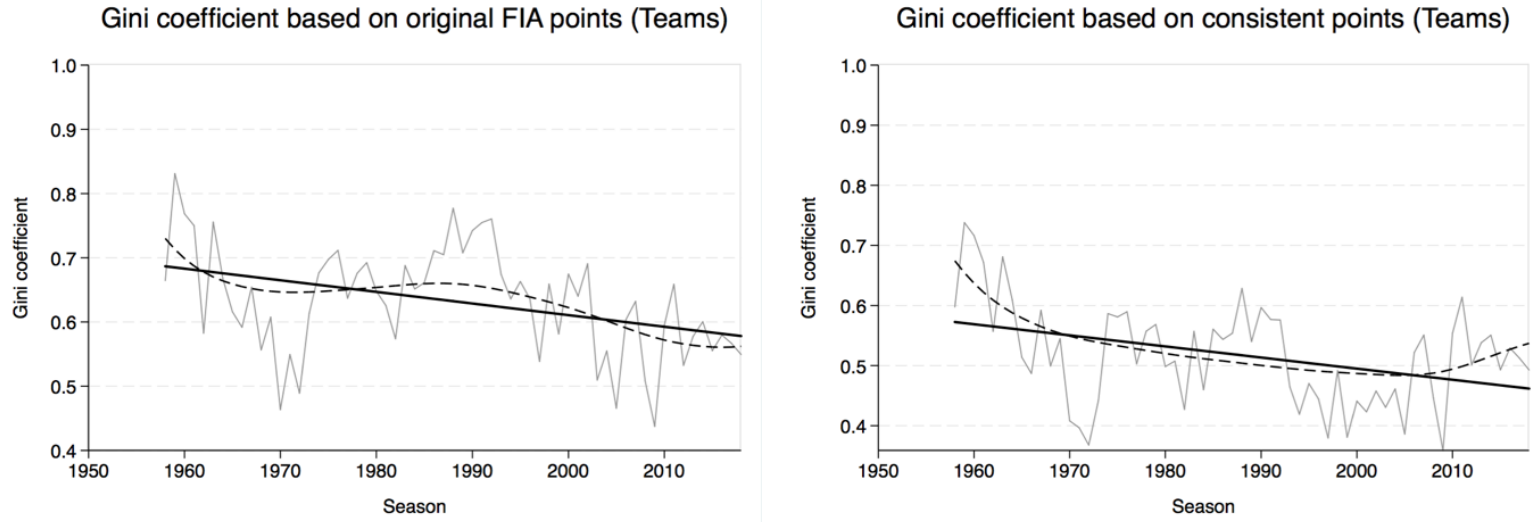

It is not easy to decide whether to use the point scheme based on the current FIA rules or the consistent but artificial point scheme. The later one has the advantage of comparability, while the first one reflects the situation the fans perceived during or at the end of the respective season. Maybe one can recommend using the artificial consistent point scheme while analyzing competitive balance for its own sake. Furthermore, if a measure of competitive balance should be used as a dependent variable in a regression to identify the reaction of consumers to changes in competitive balance, using the current FIA point scheme might be appropriate.

All examples showed so far in this section are based on the number points each driver/team accumulated at the end of a given season. Because the difference in points awarded to the top positions of the final race result are fixed, accumulated points might not reflect perceived difference on the race level. For example, winning by just one thousands of a second is equal to winning by 30 seconds. One possible solution to overcome this shortcoming of the point-based championship table is to 
use the leading distance or leading laps accumulated by the different drivers/teams. Figure 6 contains the development of the Gini coefficients calculated on the basis of accumulated leading laps or distance at the end of each season. Thereby, the left column shows the Gini coefficient using leadings laps and the right column using leading distance in kilometers.

Figure 6: Competitive balance based on leading laps and leading distance (drivers)
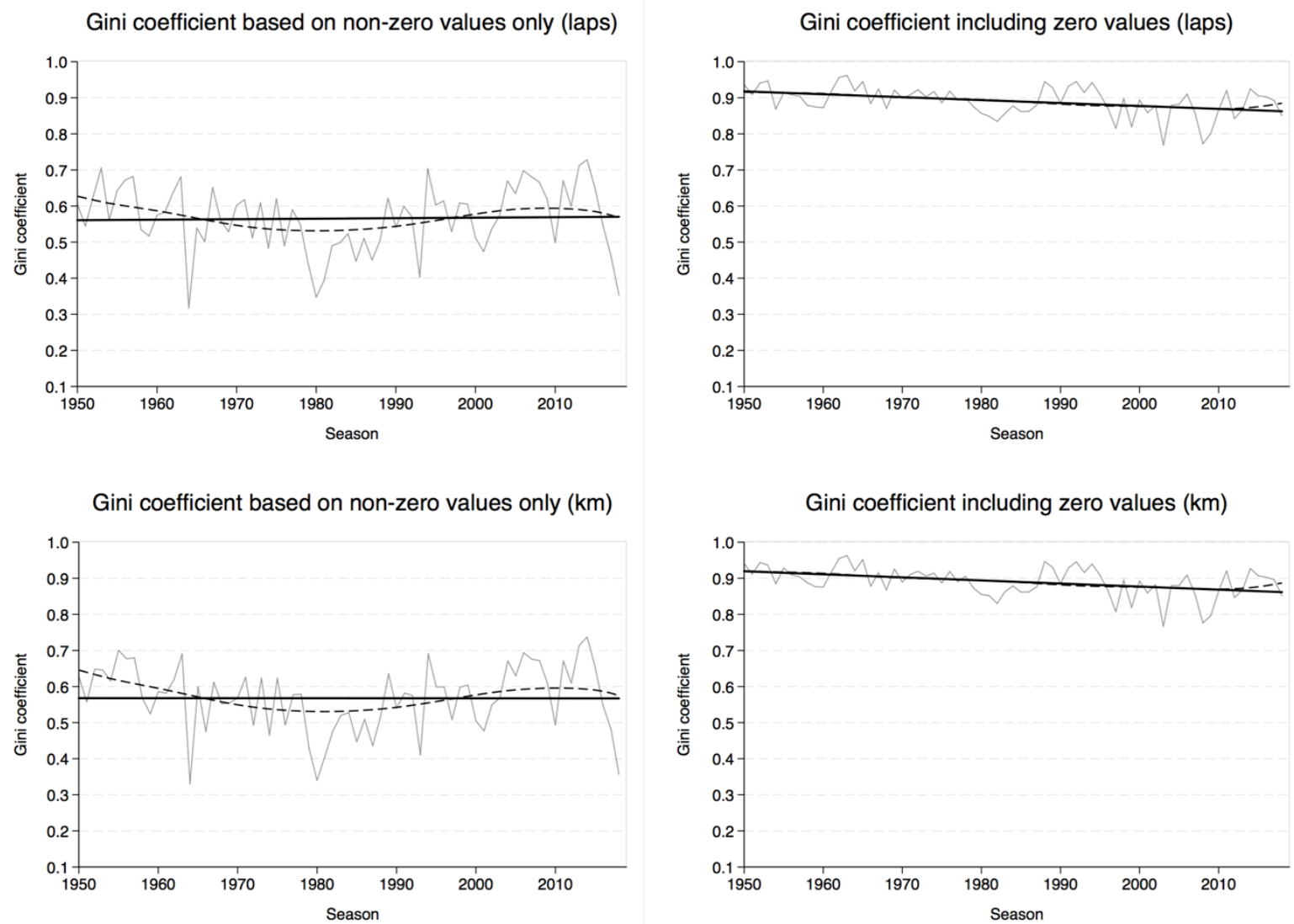

Looking at the left column of Figure 6, which displays the Gini coefficient based on divers with a non-zero number of leading laps and $\mathrm{km}$ respectively, the story seems to be a little different if compared to the Gini coefficient based on the accumulated points. Here, the long-term trend of the coefficient index is more or less stable over the observation period. The smoothed trend reveals a minimum of the Gini coefficient and thus a maximum of competitive balance somewhere around the year 1980, while ending at almost the same level as at the beginning of the observation period. Regarding values of around 0.6 , the competitions could be considered as relatively imbalanced. If also drivers without any leading laps or km are considered, F1 seems 
to be even more imbalanced, meaning that only very few drivers/teams are leading a GP over the course of a season. However, both the linear and the smoothed trend indicate a slightly negative development or - in other words - a small improvement of competitive balance over the observation period. Figure 7 depicts the same indicators but for teams instead of drivers. Here, the results are very similar to those shown in Figure 6.

Figure 7: Competitive balance based on leading laps and leading distance (teams)
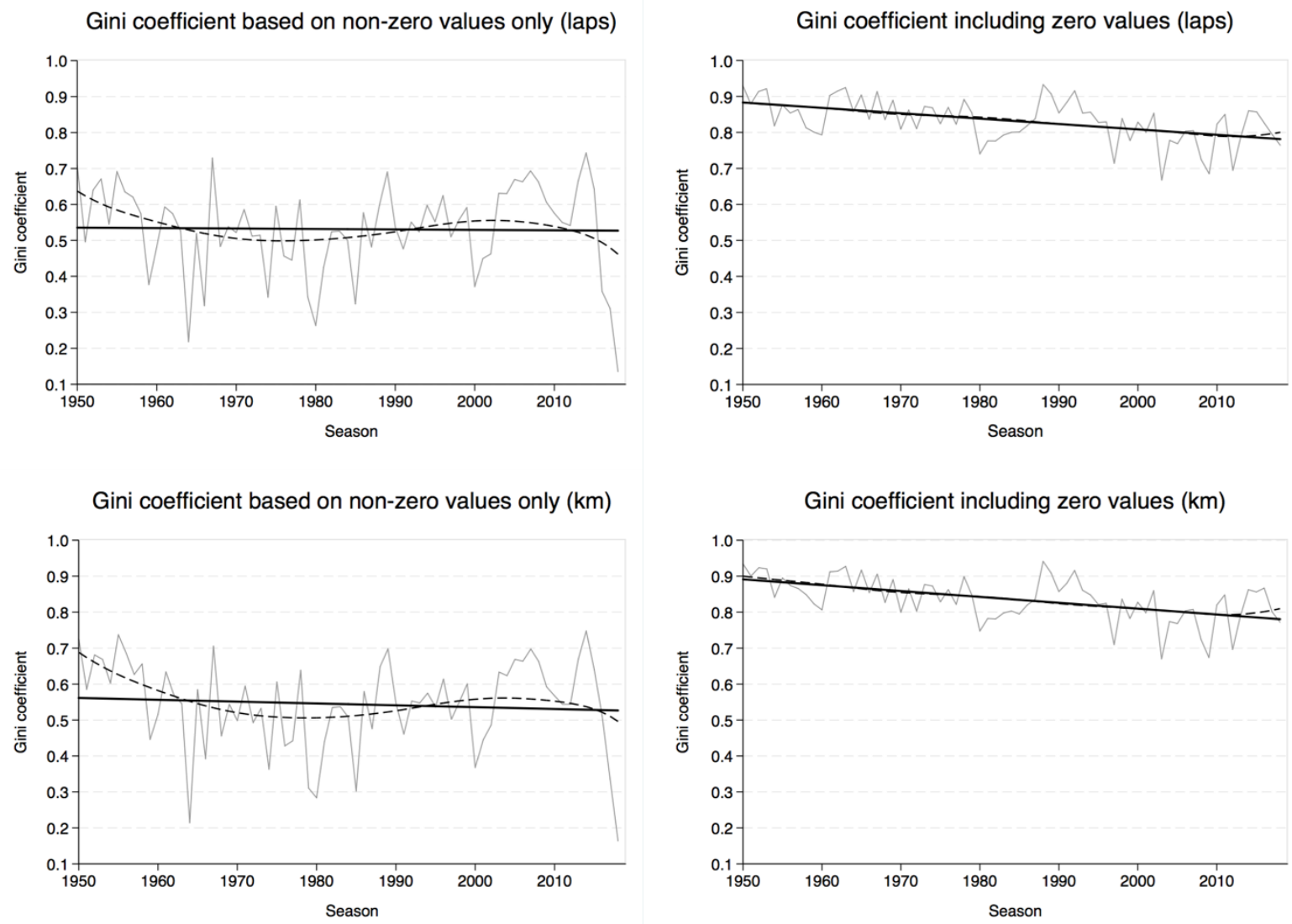

\subsection{Inter-season Competitive Balance}

Static and dynamic inter-season competitive balance might not be of such great interest from the perspective of program planners and advertising marketers because their interests are normally more short-term in nature. However, from the perspective of the championship organizer, it might be indeed an important indicator for longterm rule changes to raise the attractiveness of the competition. 
First, indicators of static inter-season competitive balance should be introduced. The measures are based on the distribution of the championship titles won by individual drivers or teams. Here, we employed also the Gini coefficient but other measures like the $\mathrm{HHI}$ or the standard deviation could have been used, too. Table 1 displays the according coefficients for the entire period from 1950 to 2018 and, additionally, also coefficients for each decade since the introduction of the F1 world championship. The first two rows of the table show the values for the WDC and the WCC. The following rows contain comparable coefficients for popular team sports leagues in Europe and North America.

Table 1: Competitive Balance based on championship distribution (Gini coefficient)

\begin{tabular}{lllllllll}
\hline \hline & $1950-$ & $1950-$ & $1960-$ & $1970-$ & $1980-$ & $1990-$ & $2000-$ & $2010-$ \\
& 2018 & 1959 & 1969 & 1979 & 1989 & 1999 & 2009 & 2018 \\
\hline F1 drivers & 0.350 & 0.360 & 0.171 & 0.171 & 0.267 & 0.171 & 0.360 & 0.222 \\
F1 teams & 0.503 & - & 0.233 & 0.300 & 0.133 & 0.350 & 0.400 & 0.056 \\
Premiere League & 0.489 & 0.267 & 0.150 & 0.300 & 0.400 & 0.360 & 0.267 & 0.194 \\
La Liga & 0.591 & 0.250 & 0.467 & 0.350 & 0.300 & 0.333 & 0.250 & 0.370 \\
Bundesliga & 0.533 & 0.171 & 0.150 & 0.350 & 0.400 & 0.280 & 0.400 & 0.278 \\
Serie A & 0.569 & 0.250 & 0.240 & 0.333 & 0.300 & 0.350 & 0.311 & 0.444 \\
MLB & 0.495 & 0.400 & 0.171 & 0.160 & 0.089 & 0.241 & 0.089 & 0.241 \\
NBA & 0.538 & 0.300 & 0.400 & 0.150 & 0.350 & 0.400 & 0.320 & 0.241 \\
NFL & 0.409 & 0.240 & 0.333 & 0.233 & 0.233 & 0.233 & 0.229 & 0.097 \\
NHL & 0.526 & 0.267 & 0.267 & 0.267 & 0.300 & 0.150 & 0.159 & 0.222 \\
\hline
\end{tabular}

It can be seen that the WDC is in many cases more balanced than the WCC. Moreover, the WDC seems to be the most balanced competition among the listed championships. Regarding the F1 driver championship, especially the decades dominated by Juan Manuel Fangio (five titles between 1951 and 1957) and Michael Schumacher (five titles between 2000 and 2004) show high values of this competitive balance indicator. Obviously, the competitive balance comparison between the WDC and any type of team sports (including the WCC) suffers from the difference in length of driver careers compared to team careers. Thus, over long periods in time (like 1950- 
2018), the indicator for the WDC will naturally differ from team sports, whereas shorter periods in time are more comparable.

In contrast to the WDC, the WCC is located at the other end of the scale joining the Spanish "La Liga", the Italian "Serie A", and the North-American "NBA" as unbalanced competitions. For the WCC, an exceptionally low coefficient can be observed during the 1980s. This decade was dominated by three teams: Ferrari, McLaren, and Williams. The last two won four of the ten constructor championships each, while Ferrari won the remaining two. It has to be stated that the choice of decades to analyze the static competitive balance for sub-periods is somewhat arbitrary. For instance, the ten-year period from 1999 to 2008, in which Ferrari has won eight of ten possible constructor championships, paints a different picture than any of the decades. Actually, the WCC shows its lowest value during the 2010-2018 period, when two teams (Red Bull Racing and Mercedes) were dominating.

\section{Conclusions and Outlook}

This paper has two main aims. First, different measures of competitive balance in F1 racing or motorsports in general are introduced. Moreover, pitfalls induced especially by the type of data or calculation method have been highlighted.

Using three different dimensions of competitive balance (within-race, within-season, inter-season) in F1 motor racing, weak evidence for improvements of competitive balance over the course of the seasons could be found, even though also trends for some measures are available indicating a decline in competitive balance. The generally positive trend seems to be reversed with respect to many indicators since 2010, though.

This analysis could be extended in several ways. First, it seems to be fruitful to analyze also the dynamic aspects of competitive balance in F1 racing. A useful tool could be the Markov chain based method developed by Hadley, Ciecka, and Krautman (2005). Here, competitive balance is measured by using the transition probabilities from one season to the following. Second, other dynamic measures like the Spearman rank 
correlation coefficient or the adjusted churning index (Berkowitz, Depken, and Wilson, 2011: 258; Mizak, Neral, and Stair, 2007) based on final standing position between two consecutive seasons could be employed.

Finally, operationalizing measures of competitive balance in motor sport racing could be important for further research in this area. F1 seems to be a particularly wellsuited field to analyze the effects of competitive balance on fan demand, especially with a view to distinguish between the effects of competitive balance and a domestic/local hero preference.

\section{References}

Badenhausen, K. (2018), Formula One star Lewis Hamilton signs \$100 million contract with Mercedes, URL: https://www.forbes.com/sites/kurtbadenhausen/ 2018/07/19/formula-one-star-lewis-hamilton-signs-100-million-contract-withmercedes/\#664ffea22abf (accessed 21.02.2019).

Bekker, J., \& Lotz, W. (2009). Planning Formula One Race strategies using discreteevent simulation. Journal of the Operational Research Society, 60(7), 952-961.

Bell, A., Smith, J., Sabel, C. E., \& Jonesm K. (2016). Formula for success: Multilevel modelling of Formula One driver and constructor performance 1950-2014. Journal of Quantitative Analysis in Sports, 12(2), 99-112.

Berkowitz, J. P., Depken, C. A., \& Wilson, D. P. (2011). When going in circles is going backward: Outcome uncertainty in NASCAR. Journal of Sports Economics, 12(3), 253-283.

Budzinski, O., \& Müller-Kock, A. (2018). Is the revenue allocation scheme of Formula One motor racing a case for European competition policy? Contemporary Economic Policy, 361), 215-233.

Budzinski, O. (2012). The institutional framework for doing sports business: Principles of EU competition policy in sports markets. International Journal of Sport Management and Marketing, 11(1-2), 44-72.

Budzinski, O. (2018). Financial regulation as an anticompetitive institution. In M. Breuer \& D. Forrest (eds.), The Palgrave Handbook on the Economics of Manipulation in Professional Sports (pp. 159-179). Basingstoke: Palgrave. 
Cygan, A. (2007). Are all sports special? Legal issues in the regulation of Formula One motor racing. European Business Law Review, 18(6), 1327-1352.

Coates, D., Humphreys, B.R., \& Zhou, L. (2014). Reference-dependent preferences, loss aversion, and live game attendance. Economic Inquiry, 52(3), 959-973.

Del Corral, J. (2009). Competitive balance and match uncertainty in Grand-Slam tennis: Effects on seeding system, gender, and court surface. Journal of Sports Economics, 106), 563-581.

Depken, C. A., Groothuis, P. A., \& Rotthoff, K. W. (2018). Family connections in motorsports: The case of Formula One. International Journal of Sports Finance, 13(4), 336-352.

Du Bois, C., \& Heyndels, B. (2007). It's a different game you go to watch: Competitive balance in men's and women's tennis. European Sport Management Quarterly, $7(2), 167-185$.

Gutiérrez, E., \& Lozano, S. (2014). A DEA approach to performance-based budgeting of Formula One constructors. Journal of Sports Economics, 15(2), 180-200.

Hadley, L., Ciecka, J., \& Krautmann, A. C. (2005). Competitive balance in the aftermath of the 1994 players' strike. Journal of Sports Economics, 6(4), 379-389.

Jenkins, M. \& S. Floyd (2001), Trajectories in the evolution of technology: A multilevel study of competition in Formula 1 racing. Organization Studies, 22(6), 945969.

Jenkins, M. (2010). Technological discontinuities and competitive advantage: A historical perspective on Formula 1 motor racing 1950-2006. Journal of Management Studies, 47(5), 884-910.

Judde, C., Booth, R., \& Brooks, R. (2013). Second place is first of the losers: an analysis of competitive balance in Formula One. Journal of Sports Economics, 14(4), 411439.

Kipker, I. (2003). Determinanten der TV-Nachfrage in der Formel 1 - Superstar- vs. Spannungseffekte und Implikationen für die Wettbewerbspolitik. In Dietl, H. (ed.), Globalisierung des wirtschaftlichen Wettbewerbs im Sport (pp. 85-103). Schorndorf: Verlag Karl Hofmann.

Koning, R. H. (2009). Sport and measurement of competition. De Economist, 157(2), 229-249. 
Konjer, M., Meier, H. E., \& Wedeking, K. (2017). Consumer demand for telecasts of tennis matches in Germany. Journal of Sports Economics, 18(4), 351-375.

Krauskopf, T., Langen, M., \& Bünger, B, (2010). The search for optimal competitive balance in Formula One. CAWM Discussion Paper, University of Münster, No. 38. Liberty Media Corporation (2019). Company history. URL: http://www.libertymedia.com/overview/company-history.html (accessed 22.02.2019).

Mastromarco, C., \& Runkel, M. (2009). Rule changes and competitive balance in Formula One motor racing. Applied Economics, 41(23), 3003-3014.

Mizak, D., Neral, J., \& Stair, A. (2007). The adjusted churn: an index of competitive balance for sports leagues based on changes in team standings over time. Economics Bulletin, 26(3), 1-7.

Mourao, P. (2017). The economics of motorsports: The case of Formula One. London: Palgrave Macmillan.

Mourao, P. (2018). Surviving in the shadows: An economic and empirical discussion about the survival of the non-winning F1 drivers. Economic Analysis and Policy, 59(C), 54-68.

Müller, A., \& Budzinski, O. (2014). The economics of motorsport centers. In O. Budzinski \& A. Feddersen (eds.), Contemporary research in sports economics (pp. 295-317). Frankfurt a.M.: Lang.

Neale, W. C. (1964). The peculiar economics of professional sports: A contribution to the theory of the firm in sporting competition and in market competition. Quarterly Journal of Economics, 78(1), 1-14.

Nimmervoll, C. (2016). Acht-Milliarden-Dollar-Deal bestätigt: Liberty kauft die Formel 1. URL: https://www.motorsport-total.com/formel-1/news/acht-milliardendollar-deal-bestaetigt-liberty-kauft-die-formel-1-16090802? wing=1 (accessed 22.02.2019).

Pawlowski, T., \& Nalbantis, G. (2019). Competitive balance: Measurement and relevance (forthcoming). In Handbook of Sports Economics, London: Sage Publications.

Philipps, A. J. K. (2014). Uncovering Formula One driver performances from 1950 to 2013 by adjusting for team and competition effects. Journal of Quantitative Analysis in Sports, 10(2), 261-278. 
Potter, J. M. (2011). Estimating the offsetting effects of driver behavior in response to safety regulation: The case of Formula One racing. Journal of Quantitative Analysis in Sports, 7(3), 1-20.

Reid, C. (2015). 20 brands that defined F1. URL: https://www.raconteur.net/businessinnovation/20-brands-that-defined-f1 (last accessed 22.02.2019).

Rottenberg, S. (1956). The baseball player's labour market. Journal of Political Economy, 64(3), 242-258.

Schreyer, D., \& Torgler, B. (2018). On the role of race outcome uncertainty in the TV demand for Formula 1 grand prix. Journal of Sports Economics, 19(2), 211-229.

Shmanske, S. (2007). Consistency or heroics: Skewness, performance, and earnings on the PGA Tour. Atlantic Economic Journal, 35(4), 463-471.

Smith, L. (2018). The top 10 most famous brands in Formula 1. URL: https://www.raconteur.net/business-innovation/the-top-10-most-famous-brands-in-formula-1 (accessed 22.02.2019).

Solitander, M., \& Solitander, N. (2010). The sharing, protection and thievery of intellectual assets: The case of the Formula 1 industry. Management Decision, 48(1), 37-57.

Stadelmann, D., \& Eichenberger, R. (2008). Wer ist der beste Formel 1 Fahrer? Eine ökonometrische Talentbewertung. Perspektiven der Wirtschaftspolitik, 9(4), 486512.

Statista (2018). Major League Baseball total league revenue from 2001 to 2017 (in billion U.S. dollars). URL: https://www.statista.com/statistics/193466/totalleague-revenue-of-the-mlb-since-2005/ (accessed 22.02.2019).

Statista (2019). Total revenue of all National Football League teams from 2001 to 2017 (in billion U.S. dollars). URL: https://www.statista.com/statistics/193457/total-league-revenue-of-the-nfl-since-2005/ (accessed 22.02.2019).

Sylt, C. (2014). Formula One speeds past the $\$ 500 m$ profits flag. URL: https://www.telegraph.co.uk/finance/newsbysector/transport/11142469/Formula-One-speeds-past-the-500m-profits-flag.html (accessed 21.02.2019).

Sylt, C. (2018a). F1 prize money crashes by $\$ 45$ million under Liberty Media. URL: https://www.forbes.com/sites/csylt/2018/08/08/f1-team-prize-money-crashes-by45-million-under-liberty-media/\#5b2e91d013f7 (accessed 21.02.2019). 
Sylt, C. (2018b). F1 sponsorship growth crashes to 10-year low. URL: https://www.forbes.com/sites/csylt/2018/08/13/f1-sponsorship-growth-slowsdown/\#4b90426f1598 (accessed 22.02.2019).

Sylt, C., \& Reid, C. (2008). Formula money 2008/09. Southwick: Money Sports Media.

Van Reeth, D. (2013). TV demand for the Tour de France: the importance of stage characteristics versus outcome uncertainty, patriotism, and doping. International Journal of Sport Finance, 8(1), 39-60.

Walthert, M. (2015). F1 team budgets: Which teams are getting the best value for their money in 2015?. URL: https://www.bleacherreport.com/articles/2550212f1-team-budgets-which-teams-are-getting-the-best-value-for-their-money-in2015 (accessed 22.02.2019). 


\section{Diskussionspapiere aus dem Institut für Volkswirtschaftslehre der Technischen Universität IImenau}

Nr. 69 Budzinski, Oliver: Empirische Ex-Post Evaluation von wettbewerbspolitischen Entscheidungen: Methodische Anmerkungen, Januar 2012.

Nr. 70 Budzinski, Oliver: The Institutional Framework for Doing Sports Business: Principles of EU Competition Policy in Sports Markets, January 2012.

Nr. 71 Budzinski, Oliver; Monostori, Katalin: Intellectual Property Rights and the WTO, April 2012.

Nr. 72 Budzinski, Oliver: International Antitrust Institutions, Juli 2012.

Nr. 73 Lindstädt, Nadine; Budzinski, Oliver: Newspaper vs. Online Advertising - Is There a Niche for Newspapers in Modern Advertising Markets?

Nr. 74 Budzinski, Oliver; Lindstädt, Nadine: Newspaper and Internet Display Advertising - Co-Existence or Substitution?, Juli 2012b.

Nr. 75 Budzinski, Oliver: Impact Evaluation of Merger Control Decisions, August 2012.

Nr. 76 Budzinski, Oliver; Kuchinke, Björn A.: Deal or No Deal? Consensual Arrangements as an Instrument of European Competition Policy, August 2012.

Nr. 77 Pawlowski, Tim, Budzinski, Oliver: The (Monetary) Value of Competitive Balance for Sport Consumers, Oktober 2012.

Nr. 78 Budzinski, Oliver: Würde eine unabhängige europäische Wettbewerbsbehörde eine bessere Wettbewerbspolitik machen?, November 2012.

Nr. 79 Budzinski, Oliver; Monostori, Katalin; Pannicke, Julia: Der Schutz geistiger Eigentumsrechte in der Welthandelsorganisation - Urheberrechte im TRIPS Abkommen und die digitale Herausforderung, November 2012.

Nr. 80 Beigi, Maryam H. A.; Budzinski, Oliver: On the Use of Event Studies to Evaluate Economic Policy Decisions: A Note of Caution, Dezember 2012.

Nr. 81 Budzinski, Oliver; Beigi, Maryam H. A.: Competition Policy Agendas for Industrializing Countries, Mai 2013. 
Nr. 82 Budzinski, Oliver; Müller, Anika: Finanzregulierung und internationale Wettbewerbsfähigkeit: der Fall Deutsche Bundesliga, Mai 2013.

Nr. 83 Doose, Anna Maria: Methods for Calculating Cartel Damages: A Survey, Dezember 2013.

Nr. 84 Pawlowski, Tim; Budzinski, Oliver: Competitive Balance and Attention Level Effects: Theore-tical Considerations and Preliminary Evidence, März 2014.

Nr. 85 Budzinski, Oliver: The Competition Economics of Financial Fair Play, März 2014.

Nr. 86 Budzinski, Oliver; Szymanski, Stefan: Are Restrictions of Competition by Sports Associations Horizontal or Vertical in Nature?, März, 2014.

Nr. 87 Budzinski, Oliver: Lead Jurisdiction Concepts Towards Rationalizing Multiple Competition Policy Enforcement Procedures, Juni 2014.

Nr. 88 Budzinski, Oliver: Bemerkungen zur ökonomischen Analyse von Sicherheit, August 2014.

Nr. 89 Budzinski, Oliver; Pawlowski, Tim: The Behavioural Economics of Competitive Balance: Implications for League Policy and Championship Management, September 2014.

Nr. 90 Grebel, Thomas; Stuetzer, Michael: Assessment of the Environmental Performance of European Countries over Time: Addressing the Role of Carbon, September 2014.

Nr. 91 Emam, Sherief; Grebel, Thomas: Rising Energy Prices and Advances in Renewable Energy Technologies, July 2014.

Nr. 92 Budzinski, Oliver; Pannicke, Julia: Culturally-Biased Voting in the Eurovision Song Contest: Do National Contests Differ?, December 2014.

Nr. 93 Budzinski, Oliver; Eckert, Sandra: Wettbewerb und Regulierung, März 2015.

Nr. 94 Budzinski, Oliver; Feddersen, Arne: Grundlagen der Sportnachfrage: Theorie und Empirie der Einflussfaktoren auf die Zuschauernachfrage, Mai 2015.

Nr. 95 Pannicke, Julia: Abstimmungsverhalten im Bundesvision Song Contest: Regionale Nähe versus Qualität der Musik, Oktober 2015.

Nr. 96 Budzinski, Oliver; Kretschmer, Jürgen-Peter: Unprofitable Horizontal Mergers, External Effects, and Welfare, October 2015. 
Nr. 97 Budzinski, Oliver; Köhler, Karoline Henrike: Is Amazon The Next Google?, October 2015.

Nr. 98 Kaimann, Daniel; Pannicke, Julia: Movie success in a genre specific contest: Evidence from the US film industry, December 2015.

Nr. 99 Pannicke, Julia: Media Bias in Women's Magazines: Do Advertisements Influence Editorial Content?, December 2015.

Nr. 100 Neute, Nadine; Budzinski, Oliver: Ökonomische Anmerkungen zur aktuellen Netzneutralitätspolitik in den USA, Mai 2016.

Nr. 101 Budzinski, Oliver; Pannicke, Julia: Do Preferences for Pop Music Converge across Countries? - Empirical Evidence from the Eurovision Song Contest, Juni 2016.

Nr. 102 Budzinski, Oliver; Müller-Kock, Anika: Market Power and Media Revenue Allocation in Professonal Sports: The Case of Formula One, Juni 2016.

Nr. 103 Budzinski, Oliver: Aktuelle Herausforderungen der Wettbewerbspolitik durch Marktplätze im Internet, September 2016.

Nr. 104 Budzinski, Oliver: Sind Wettbewerbe im Profisport Rattenrennen?, Februar 2017.

Nr. 105 Budzinski, Oliver; Schneider, Sonja: Smart Fitness: Ökonomische Effekte einer Digitalisierung der Selbstvermessung, März 2017.

Nr. 106 Budzinski, Oliver; Pannicke, Julia: Does Popularity Matter in a TV Song Competition? Evidence from a National Music Contest, April 2017.

Nr. 107 Budzinski, Oliver; Grusevaja, Marina:Die Medienökonomik personalisierter Daten und der Facebook-Fall, April 2017.

Nr. 108 Budzinski, Oliver: Wettbewerbsregeln für das Digitale Zeialter - Die Ökonomik personalisierter Daten, Verbraucherschutz und die 9.GWB-Novelle, August 2017.

Nr. 109 Budzinski, Oliver: Four Cases in Sports Competition Policy: Baseball, Judo, Football, and Motor Racing, September 2017.

Nr. 110 Budzinski, Oliver: Market-internal Financial Regulation in Sports as an Anticompetitive Institution, October 2017.

Nr. 111 Bougette, Patrice; Budzinski, Oliver; Marty, Frédéric: EXPLOITATIVE ABUSE AND ABUSE OF ECONOMIC DEPENDENCE: WHAT CAN WE LEARN FROM THE INDUSTRIAL ORGANIZATION APPROACH?, December 2017. 
Nr. 112 Budzinski, Oliver; Gaenssle, Sophia: The Economics of Social Media Stars: An Empirical Investigation of Stardom, Popularity, and Success on YouTube, Januar 2018.

Nr. 113 Gaenssle, Sophia; Budzinski, Oliver; Astakhova Daria: Conquering the Box Office: Factors, influencing Success of International Movies in Russia, Mai 2018.

Nr. 114 Budzinski, Oliver; Stöhr, Annika: Die Ministererlaubnis als Element der deutschen Wettbewerbsordnung: eine theoretische und empirische AnaIyse, Juli 2018.

Nr. 115 Budzinski, Oliver; Kuchinke, Björn A.: Modern Industrial Organization Theory of Media Markets and Competition Policy Implications, September 2018.

Nr. 116 Budzinski, Oliver; Lindstädt-Dreusicke, Nadine: The New Media Economics of Video-on-Demand Markets: Lessons for Competition Policy, Oktober 2018.

Nr. 117 Budzinski, Oliver; Stöhr, Annika: Competition Policy Reform in Europe and Germany - Institutional Change in the Light of Digitization, November 2018.

Nr. 118 Budzinski, Oliver; Noskova, Victoriia; Zhang, Xijie: The Brave New World of Digital Personal Assistants: Benefits and Challenges from an Economic Perspective, December 2018.

Nr. 119 Bougette, Patrice; Budzinski, Oliver \& Marty, Frédéric: EXPLOITATIVE ABUSE AND ABUSE OF ECONOMIC DEPENDENCE: WHAT CAN WE LEARN FROM AN INDUSTRIAL ORGANIZATION APPROACH? [Updated Version 2018], December 2018.

Nr. 120 Bartelt, Nadja: Bundling in Internetmärkten - Ökonomische Besonderheiten, Wettbewerbseffekte und Regulierungsimplikationen, Dezember 2018. 